\title{
Bullies, Victims and Provocative Victims in Context: Discriminant Factors in a Portuguese Adolescent Sample
}

\author{
Marina Carvalho, (PhD) \\ ISMAT Centre for Research in Psychology \\ \& Psychiatry Department of CHA, Portugal \\ Catia Branquinho, (MSc) \\ Aventura Social/ Faculty of Human Kinetics/ University of Lisbon, Portugal \\ Margarida Gaspar de Matos, (PhD) \\ ISAMB/ University of Lisbon \& WJCR/ISPA, Portugal
}

doi: 10.19044/esj.2017.v13n20p23 URL:http://dx.doi.org/10.19044/esj.2017.v13n20p23

\begin{abstract}
Context: With strong and serious impacts on health and individual well-being, bullying presents itself as one of the most traumatic experiences at school age. Objective: analyse the differences between bullies, victims and provocative-victims for individual, relational, school and contextual factors. Design: cross-sectional study based on the 2014 Health Behaviour in School-aged Children study. Results: Bullies reported consuming more tobacco and drugs, but less alcohol, when compared to victims and provocative-victims. Bullies also reported being more involved and having more security feelings at school, better relationships with their peers, being better accepted by the peers, and more positive attitudes, compared to victims and provocative-victims; which reported more fear, sadness, rejection feelings, and also, more withdrawal at school. Group differences were also found in the time spent with friends in everyday life, nigh outs and well-being, with bullies presenting the higher odds. Provocative-victims reported involving more in fights than victims. Otherwise, bullies reported making friends more easily and spending more time with friends after school. Conclusions: Given the different characteristics and impacts of bullying on victims, bullies and provocative-victims, it is essential to consider the interrelations of groups and focus on a more engaging perspective, based on an ecological intervention model. A strong argument is also made related to the need to include young people participation in the definition of public policies to prevent peer related violence, as well as a
\end{abstract}


need to focus not only in the prevention of peer related violence, but also to focus on violence-free, positive relationships.

Keywords: Bullying; emotional symptoms, risk behaviours, relational factors, school environment, adolescents

\section{Introduction}

Widely studied in the field of social and human sciences and recognized by adolescents as an inherent problem of school life, bullying constitutes a universal health problem, with serious impacts on physical, mental and social well-being of the individual.

Although recent studies reveal a decreasing tendency in the involvement in bullying situations, the experience of this form of violence continues to be common in a large part of the European countries. The Health Behavior in School-aged Children study (HBSC) of the World Health Organization (WHO), conducted with 6026 students from $6^{\text {th }}, 8^{\text {th }}$ and $10^{\text {th }}$ grade ( $M=13.77$ years), revealed that approximately $30 \%$ of the participants reported being bullying victims (Chester et al., 2015; Elgar et al., 2015). In Portugal, one of the participant countries of the study, the situation is corroborated: $34 \%$ of the youths involved in the study $(\mathrm{N}=6026 ; M=13.77$ years), reported being provoked at least once a week in the last two months, and $4.7 \%$ reported the same situation several times a week (Matos, Simões, Camacho, Reis \& Equipa Aventura Social, 2015).

Defined as an aggressive and intentional behavior, repeated along the time in the context of interpersonal relationships characterized by an unbalance of power (Olweus, 1996; Olweus 1997), and with a destructive effect at short and long term, bullying is one of the most traumatic experiences lived in the school age (García \& Magallo 2014). Those involved in bullying situations report more health problems and less emotional and social adjustment (Nansel, Overpeck, Pilla, Ruan, SimonsMorton \& Scheidt, 2001; Nansel, Craig, Overpeck, Saluja, Ruan \& HBSC Bullying Analyzes Working Group, 2004), psychological distress and lower well-being (Thomas, Chan, Scott, Connor, Kelly \& Williams, 2016). Prevention of emotional problems and bullying behaviors is an important action in mental and adolescent health improvement (Matos, Carvalho \& Social Adventure Project Team, 2014).

Enhancing of serious impacts on a wide range of areas of an individual's life, bullying has different impacts on victims, bullies and provocative-victims lives, being common more difficulty in making friends, more loneliness and less independence among the victims (Nansel, Overpeck, Pilla, Ruan, Simons-Morton \& Scheidt, 2001). According to Lester and Mander (2015), having more support from peers and a higher 
perception of safety promote a decrease of the frequency of victimization episodes and hinder the reduction of bullying situations. According to Harel-

Fisch and colleagues (2011), more involvement in bullying situations is associated to the understanding of the school experiences as negatives. In victim's condition, a smaller school involvement and education progression is recognized (Eisenberg, Neumark-Sztainer \& Perry 2003).

Often associated with a higher socioeconomic level (Cosma, Róbert \& Baban, 2015), bullies reveal more frequency of smoking behaviors (susceptibility for use, experimentation and current consumption) (Calleja, 2016), increased risk of alcohol consumption (Vieno, Gini \& Santinello, 2011), possibly due to their high level of social integration (Archimi \& Kuntsche, 2014), and a propensity to drug use three times higher that youth not involved in bullying behaviors (Valdebenito, Ttofi \& Eisner, 2015).

Finally, in a distinct condition, given the combination of social withdrawl, less academic achievement and more involvement in risk behaviors, the provocative victims appear as a group of heightened risk (Nansel, Overpeck, Pilla, Simons-Morton \& Scheidt, 2001).

Thus, given the different characteristics and bullying impacts on different groups, it is important start considering the complex interrelationships, removing the focus on individual characteristics (Hong \& Espelage, 2012). To protect youth of the bullying effects, and knowing that is strongly associated to cyberbullying, suggesting a polyaggression, is fundamental and urgent develop policies and programs adapted to this reality (Modecki, Minchin, Harbaugh, Guerra \& Runions, 2014).

Interventions and programs focused on the ecological model (Bronfenbrenner, 1976; 1977), based on a micro (relationships with parents, peers, school involvement and educational environment), meso (teacher involvement), exo (exposure to violence in the media and neighborhood) macro (cultural beliefs and norms, religious affiliation) and chrono context (changes in family structure) (Bronffenbrenner, 1994), allied to an early process of involvement of youth in their problems identification and strategies for their resolution (Matos, 2014; Matos, 2015; Matos et al., 2015), can help achieve effective and perdurable changes.

The main goal of the present study was to analyse the differences between bullies, victims and provocative-victims for individual, relational, school and contextual factors. 
I.

\section{Method}

\section{Participants}

The 2014 wave of the Portuguese sample of the HBSC included 6026 adolescents, 47,7\% male, aged between 10 and 19,92 years old (mean age of 13,77 years old), in the $6^{\text {th }}(35.8 \%), 8^{\text {th }}(39.1 \%)$, and $10^{\text {th }}$ school year (25.1\%), randomly assigned from national schools and stratified, representing all the country.

Table 1 shows the demographic characteristics of the sample. Details on the other demographic characteristics can be found in Matos and Social Adventure Team (2015).

Table 1 - Demographic characteristics of the sample

\begin{tabular}{cccccccc}
\hline & $\mathrm{N}$ & $\%$ & $\mathrm{M}$ & $\mathrm{DP}$ & Range. & Skweness & Curtosis \\
\hline Gender & & & & & & & \\
Male & 2872 & 47.7 & & & & \\
Female & 3154 & 52.3 & & & & \\
School Grade & & & & & & \\
$6^{\text {th }}$ year & 2157 & 35.8 & & & & \\
$8^{\text {th }}$ year & 2358 & 39.1 & & & & \\
10 & & & \\
Region & 1511 & 25.1 & & & & \\
$\quad$ North & 2506 & 41.6 & & & & \\
Lisbon and & 1217 & 20.2 & & & & \\
Vale do Tejo & & & & & & \\
$\quad$ Centre & 1031 & 17.1 & & & & \\
Alentejo & 755 & 12.5 & & & & \\
Algarve & 517 & 8.6 & & & & \\
\hline Age & 6026 & 100 & 13.77 & 1.68 & $10-20$ & .825 \\
\hline
\end{tabular}

\section{Measures}

The questionnaire (Currie, et al. 2012) includes a demographic data section and the assessment of school environment, alcohol, drugs and tobacco consumption, peer related violence, physical activity and hobbies, nutrition, security, psychosocial health, general symptoms, sexuality, social relationships and social support. Each questionnaire requires about 55 minutes to be administered (see Table 2).

Table 2 - Items used and range

\begin{tabular}{cc}
\hline Items & Range \\
\hline Smoking consumption & $1-4$ (everyday/don't smoke)* \\
Alcohol consumption & $1-5$ (everyday/never)* \\
Drugs consumption & $1-4$ (never/regularly) \\
School involvment & $1-4$ (like it very much/not at all)* \\
Relationhips with peers & $1-5$ (strongly agree/strongly disagree) $^{*}$ \\
Peers attitudes & $1-5$ (strongly agree/strongly disagree) $^{*}$ \\
Peers acceptance & $1-5$ (strongly agree/strongly disagree) $^{*}$ \\
Security feelings at school & $1-5$ (always/never)* \\
Fear & $1-5$ (almost everyday/rarely or never)* $^{*}$
\end{tabular}


Sadness

Rejection feelings

Withdrawl at school

Involvment in fights

Money

Friends in everyday life

Virtual friends

Making friends

Time spent with friends after school
1 - 5 (almost everyday/rarely or never)*

$1-5$ (strongly agree/strongly disagree)*

1 - 5 (never happened during the last 2 months/several times during week)

$1-5$ (never/four times or more)

$$
0-500 \text { euros }
$$

$1-4$ (none/three or more)

$1-4$ (none/three or more)

$1-4$ (very easy/very difficult)*

$0-6$ (none/ 6 days)

Night outs

$0-7$ (none/ 7 days)

* reverted items.

\section{Procedure}

The schools that took part on the sampling process were randomly selected from the national schools list, and stratified by educational regions. In each school, a random selection of classes was carried out and the questionnaire was administered by the teachers in the computer room, online, assisted by the NT teachers, after parental and students' informed consent to volunteer and anonymous participation in the study. Details on the procedures for data collection in the HBSC Study can be consulted in Matos and Social Adventure Team (2015).

\section{Statistical analysis}

SPSS 22.0 for Windows (SPSS, Chicago IL, USA) was used in order to carry out univariate ANOVAs and discriminant multivariate analyses, comparing the different groups. Post-hoc tests were performed according to Tukey method.

\section{Results}

Table 3 shows the descriptive data obtained for each of the three bullying groups, victims, bullies and provocative victims.

Table 3 - Comparisons, according to provocation status, for emotional symtoms, contextual and relational factors

\begin{tabular}{|c|c|c|c|c|c|c|c|}
\hline & \multicolumn{2}{|c|}{$\begin{array}{l}\text { Victims (a) } \\
(\mathrm{N}=925)\end{array}$} & \multicolumn{2}{|c|}{$\begin{array}{l}\text { Bullies (b) } \\
(\mathrm{N}=498)\end{array}$} & \multicolumn{2}{|c|}{$\begin{array}{c}\text { Provocative- } \\
\text { victims (c) } \\
(\mathrm{N}=1192)\end{array}$} & \multirow[t]{2}{*}{$\mathrm{F}$} \\
\hline & $\mathrm{M}$ & SD & $\mathrm{M}$ & SD & $\mathrm{M}$ & SD & \\
\hline $\begin{array}{c}\text { Smoking } \\
\text { consumption }\end{array}$ & -.03 & .94 & .28 & 1.44 & .06 & 1.07 & $13.11 * * * *^{\mathrm{b}>\mathrm{a}, \mathrm{c}}$ \\
\hline $\begin{array}{c}\text { Alcohol } \\
\text { consumption }\end{array}$ & -.05 & .89 & .19 & 1.27 & .13 & 1.18 & $11.3^{* * * b<a, c}$ \\
\hline $\begin{array}{c}\text { Drugs } \\
\text { consumption }\end{array}$ & -.05 & .72 & .36 & 1.79 & .05 & 1.16 & $13.6^{* * * \mathrm{~b}>\mathrm{a}, \mathrm{c}}$ \\
\hline School & -.01 & 1.01 & -.18 & 1.04 & -.18 & 1.05 & $8.1 * * * \mathrm{~b}>\mathrm{a}, \mathrm{c}$ \\
\hline
\end{tabular}




\begin{tabular}{|c|c|c|c|c|c|c|c|}
\hline involvment & & & & & & & \\
\hline $\begin{array}{l}\text { Relationhips with } \\
\text { peers }\end{array}$ & -.20 & 1.06 & .01 & .95 & -.23 & 1.10 & $9.1^{* * *} \mathrm{~b}>\mathrm{a}, \mathrm{c}$ \\
\hline Peers attitudes & -.12 & 1.01 & .07 & .98 & -.15 & 1.09 & $9.3^{* * *} \mathrm{~b}>\mathrm{a}, \mathrm{c}$ \\
\hline Peers acceptance & -.30 & 1.12 & .15 & .86 & -.31 & 1.13 & $36.6^{* * *} \mathrm{~b}>\mathrm{a}, \mathrm{c}$ \\
\hline $\begin{array}{c}\text { Security feelings } \\
\text { at school }\end{array}$ & -.24 & 1.03 & -.03 & 1.11 & -.28 & 1.03 & $9.6^{* * *} \mathrm{~b}>\mathrm{a}, \mathrm{c}$ \\
\hline Fear & .22 & 1.15 & -.08 & .92 & .20 & 1.15 & $14.4^{* * * a, c>b}$ \\
\hline Sadness & .24 & 1.16 & -.02 & .98 & .25 & 1.17 & $12.3^{* * * a, c>b}$ \\
\hline Rejection feelings & .20 & 1.02 & -.06 & 1.03 & .15 & 1.01 & $11.8^{* * * a, c>b}$ \\
\hline $\begin{array}{c}\text { Withdrawl at } \\
\text { school }\end{array}$ & .24 & 1.22 & -.05 & .89 & .31 & 1.27 & $16.1 * * * a, \mathrm{a}>\mathrm{b}$ \\
\hline $\begin{array}{l}\text { Involvment in } \\
\text { fights }\end{array}$ & -.02 & .95 & .26 & 1.23 & .52 & 1.33 & $54.1^{* * * \mathrm{c}>\mathrm{b}>\mathrm{a}}$ \\
\hline Money & -.01 & 1.01 & .12 & 1.37 & .04 & 1.14 & 1.8 \\
\hline $\begin{array}{l}\text { Friends in } \\
\text { everyday life }\end{array}$ & -.14 & 1.10 & .06 & .95 & -.06 & 1.07 & $5.7 * * \mathrm{~b}>\mathrm{a}, \mathrm{c}$ \\
\hline Virtual friends & .05 & 1.01 & .03 & 1.01 & .13 & 1.11 & 2.2 \\
\hline Making friends & -.21 & $1-08$ & -17 & -93 & -.02 & 1.04 & $20.61 * * * b>c>a$ \\
\hline $\begin{array}{l}\text { Time with friends } \\
\text { after school }\end{array}$ & -.10 & 1.02 & .20 & .96 & .05 & .99 & $15.4^{* * *} \mathrm{~b}>\mathrm{c}>\mathrm{a}$ \\
\hline Night outs & -.08 & .88 & .26 & 1.27 & .16 & 1.19 & $19.2^{* * * \mathrm{~b}>\mathrm{a}, \mathrm{c}}$ \\
\hline Well-being & -.26 & 1.06 & .06 & .99 & -.16 & 1.04 & $14.5^{* * * \mathrm{~b}>\mathrm{a}, \mathrm{c}}$ \\
\hline
\end{tabular}

Significant differences were found for smoking, $F(2 ; 2604)=13.11$, $p=.0001$, alcohol, $F(2 ; 2611)=11.3, p=.0001$, and drugs consumption, $F$ $(2 ; 1655)=13.6, p=$. 0001. Bullies-reported smoking more, consuming more drugs and drinking less alcohol, compared to victims and provocative victims.

Bullies also reported a greater school involvement, $F(2 ; 2611)=8.1$, $p=.0001$, better relationships with peers, $F(2 ; 2611)=9.1, p=.0001$, attitudes, $F(2 ; 2611)=9.3, p=.0001$, peers acceptance, $F(2 ; 2611)=36.6$, $p=.0001$, and more security feelings at school, $F(2 ; 2594)=9.6, p=$. 0001, compared to victims and provocative victims.

On the other hand, victims and provocative victims reported more fear, $F(2 ; 2612)=14.4, p=.0001$, sadness, $F(2 ; 2612)=12.3, p=.0001$, rejection feelings, $F(2 ; 2611)=11.8, p=.0001$ and, also, withdraw themselves more at school, $F(2 ; 2382)=16.1, p=.0001$.

Group differences were also found in the time spent with friends in everyday life, $F(2 ; 2373)=5.7, p=.0001$, night outs, $F(2 ; 2384)=19.2, p$ $=.0001$, and well-being, $F(2 ; 2389)=14.5, p=.0001$. Bullies reported spending more time with friends in everyday life, more night outs and wellbeing compared to victims and provocative victims.

Finally, provocative victims reported involving more in fights, $F$ (2; 2592) $=54.1, p=.0001$, than bullies and bullies also reported involving 
more in fights than victims. Bullies reported making friends more easily and spending more time with friends after school compared to provocative victims; provocative victims also reported making friends more easily and spending more time with friends after school compared to victims, $F$ (2; $2347)=20.61, p=.0001$, and $F(2 ; 2384)=15.4, p=.0001$, respectively.

A multivariate discriminant analysis was carried out, using stepwise method, allowing to successfully discriminate the three groups, and showing two statistically discriminant functions, function 1 (x), Wilks' $\lambda=.89 ; \chi^{2}$ $(12)=171.22 ; \mathrm{p}=.0001$, and function 2 (y), Wilks' $\lambda=.96 ; \chi^{2}(5)=56.35$; $p=.0001$. Table 4.

The coordinates of the centroids for the three groups are presented in Table 4 - Functions at group centroids

\begin{tabular}{ccc}
\hline & F1 & F2 \\
\hline Victims & -.280 & -.183 \\
Bullies & .520 & -.165 \\
Provocative victims & -.010 & .226 \\
\hline
\end{tabular}

According to these coordinates, Figure 1 represents the three groups (cyberbullies, cybervictims and cyberbullies-victims), from their centroids within the discriminant functions.

Figure 1 - Graphical representation of the groups based on the centroids values and of the discriminative variables

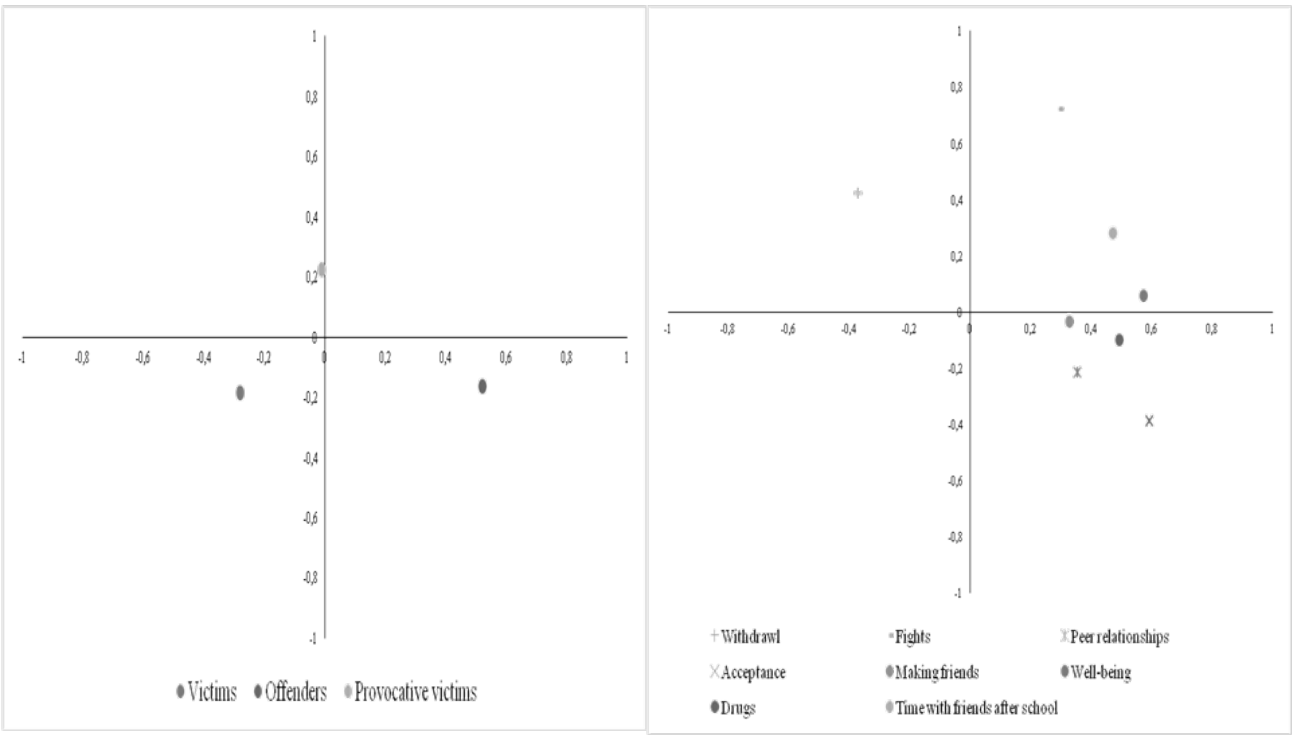

The graphical representation of the functions discriminated the three groups. Bullies are graphically represented on the positive side of the first function and on the negative side of the second function. Victims are 
represented on the negative side of both functions and provocative victims are represented on the negative side of the first function and on the positive side of the second function. These results show that the discriminant function discriminated the three groups, victims, bullies and provocative victims.

The description of the discriminant functions from the studied variables ordered by the magnitude of the correlations with those functions can be also seen in Figure 1. According to Hair, Anderson, Tatham and Black (1998), we considered correlations above 0.30 statistically significant.

Thus, the first function was defined on the positive side for peers acceptance, well-being, drugs consumption, time spent with friends after school, peer relationships, making friends and involvement in fights and, on the negative side, for withdrawal. The second function was defined on the positive side for well-being, time spent with friends after school, involvement in fights and withdrawal and, on the negative side for peers acceptance, drugs consumption, relationships with peers and readiness in making friends.

Additionally, Table 5 shows that the analysis of the discriminant function indicated that $46.4 \%$ of victims, $7.8 \%$ of bullies and $68.9 \%$ of provocative-victims were correctly classified.

Table 5 - Matrix structure

\begin{tabular}{ccc}
\hline & F1 & F2 \\
\hline Peers acceptance & $.592^{*}$ & $-.387^{*}$ \\
Well-being & $.573^{*}$ & .059 \\
Drugs & $.493^{*}$ & -.098 \\
Time with friends after school & $.473^{*}$ & .281 \\
Peer relationships & $.355^{*}$ & -.213 \\
Making friends & $.328^{*}$ & -.035 \\
Sadness & -.058 & .290 \\
Rejection feelings & -.188 & .277 \\
Peer Attitudes & .274 & -.116 \\
Night outs & .267 & .165 \\
Security feelings at school & .235 & -.141 \\
Smoking & .220 & .011 \\
Alcohol & .209 & .056 \\
Friends in everyday life & .196 & -.091 \\
Fear & -.073 & .189 \\
Involvment in fights & $.296^{*}$ & $.724^{*}$ \\
Withdrawl & $-.371^{*}$ & $.422^{*}$ \\
School involvment & .000 & .114 \\
\hline
\end{tabular}

* correlation values superior to .30 between the variable and the discriminant function.

The global results of the classification, with $48.4 \%$ of the participants correctly classified have shown that withdrawal discriminated provocative victims from bullies and victims and that peers relationships and acceptance, drugs consumption, time spent with friends after school, readiness in making 
friends, involvement in fights and well-being discriminated bullies from victims and provocative victims.

\section{Conclusion}

Past four decades after the first bullying investigation accomplished by Olweus, and recognized the important implications of this way of violence in the life of those involved, many were the studies developed to the date. However, face to the dimension and extension of this phenomenon, and if we consider that approximately three in each ten youths in school age (Chester et al., 2015; Elgar et al., 2015) are involved in bullying behaviors, we realize that much work is still to be developed.

In this investigation, to promote a larger scientific knowledge related with the theme of bullying, the discriminant factors among victims, bullies and provocative-victims were studied. Statistically significant differences were found in tobacco, alcohol and drugs consumption. In contrast to the study developed by Luk, Wang and Simons-Morton (2010), in this analysis were bullies who showed a higher consumption of all substances, when compared to victims and provocative victims. Associated with increased consumption and use of multiple substances, bullies are also recognized for their antisocial behavior (Cerezo \& Méndez, 2013) and expression of externalizing problems when compared with victims (Valdebenito, Ttofi \& Eisner, 2015).

However, despite the large number of risk behaviors, when compared with victims and provocative victims, the bullies reported a higher school involvement, better relationships with peers, attitudes, peer acceptance and more security' feelings at school. With an easiness of social integration (Archimi \& Kuntsche, 2014), the provocateurs reveal greater ease in making friends (Nansel, Overpeck, Pilla, Ruan, Simons-Morton \& Scheidt, 2001), social time (on the day and after school), more night outs, as well as more well-being.

Certainly promoted by the discomfort appealing from violence actions (Olweus 1996), isolation and loneliness felt at the school (Olweus 1997), victims are prone to fear, sadness, and rejection feelings, and withdraw themselves more at school. Victims of social exclusion, reveal a weak attachment and a poor development of social competences (Due et al., 2015).

Finally, but maybe a reason of a larger concern, if we consider their double condition, provocative victims, although they demonstrate a superior capacity to make friends and more time dedicated to them after school, when compared to victims, this is the group more involved in fights. 
Focuses or agents of violence behaviors, victims, bullies and provocative victims are youth with immediate need of intervention. Due to the consequences for mental health and school functioning deterioration, fomented by high involvement levels in bullying situations (Renshaw, Roberson \& Hammons, 2016), it is important to adjust efforts for the development of future interventions adapted the youths' true needs and current society. Recognizing the merit of the use of an ecological model in a micro, meso, exo, macro and chrono perspective (Bronfenbrenner, 1994) but being known that it is necessary Competence, Motivation and Opportunity (COM-B model) for a durable change, and that these are essential action strategies not only for people but also for the institutions and political changes (Mitchie, van Stralen \& West, 2011), the adaptation or development of new interventions anti-bullying as well as theoretical models is of most importance.

On the basis of a multidimensional perspective, focused on the involvement of youth in the process of identification of their necessities and proposals for their problems (Matos, 2014; Matos et al., 2015; Matos, 2015); an adaptation or development of school programs to prevent bullying, focusing not only on this traditional form of violence but also in cyberbullying (Brown, Demaray \& Secord, 2014); a greater awareness and education of youth (Alim, 2016).

Based on the results, and given the different characteristics and impacts of bullying on victims, bullies and bullies, victims, it is essential to consider the interrelations of groups and focus on a more engaging perspective, based on a model of ecological intervention. A strong argument is also made related to the need to include young people participation in the definition of public policies to prevent peer related violence, as well as a need to focus not only in the prevention of peer related violence, but also to focus on violence-free, positive relationships.

\section{References:}

1. Alim, S. (2016). Cyberbullying in the World of Teenagers and Social Media: A Literature Review. International Journal of Cyber Behavior, Psychology and Learning, 6(2), 68-95. doi: 10.4018/IJCBPL.2016040105

2. Archimi, A., \& Kuntsche, E. (2014). Do bullies and victims drink for different reasons? Testing mediation of drinking motives in the link between bullying subgroups and alcohol use in adolescence. Addictive Behaviors, 39, 713-716. doi: 10.1010/j.addbeh.2013.11.011

3. Bronfenbrenner, U. (1976). The Experimental Ecology of Education. Educational Researcher, 5(9), 5-15. doi: 10.3102/0013189X005009005 
4. Bronfenbrenner, U. (1977). Toward an experimental ecology of human development. American Psychologist, 32(7), 513-531. doi: 10.1037/0003-066X.32.7.513

5. Bronfenbrenner, U. (1994). Ecological models of human development. In Husen, T. \& Postlethwaite, T.N. (Eds.), International Encyclopedia of Education, 3(2) (1643-1647). England: Pergamon Press.

6. Brown, C.F., Demaray, M.K. \& Secord, S.M. (2014). Cyber victimization in middle school and relations to social emotional outcomes. Computers in Human Behavior, 35, 12-21. doi: 10.1016/j.chb.2014.02.014

7. Calleja, N. (2016). Bullying y Tabaco: ¿Se Encuentran Asociados? [Bullying and Tobacco: Are they related?]. Acta de Investigación Psicológica, 6(1), 2350-2367.

8. Cerezo, F. \& Méndez, I. (2013). Agresores en bullying y conductas antisociales. [Bullying aggressors and antisocial behaviors]. European Journal of Investigation in Health, Psychology and Education, 3(1), 5-14. doi: 10.1989/ejihpe.v3i1.19

9. Chester, K. L., Callaghan, M., Cosma, A., Donnelly, P., Craig, W., Walsh, S., \& Molcho, M. (2015). Cross-national time trends in bullying victimization in 33 countries among children aged 11, 13 and 15 from 2002 to 2010. The European Journal of Public Health, 25(2), 61-64. doi: 10.1093/eurpub/ckv029

10. Cosma, A., Róbert, B., \& Băban, A. (2015). Time Trends in Bullying Involvement among Romanian School Aged Children from 2006 to 2014. Procedia - Social and Behavioral Sciences, 209, 17-24. doi:10.1016/j.sbspro.2015.11.221

11. Currie, C. et al. (Eds.) (2012). Social determinants of health and wellbeing among young people. Health Behaviour in School-aged Children (HBSC) study: international report from the 2009/2010 survey. Copenhagen: WHO Regional Office for Europe (Health Policy for Children and Adolescents, No. 6).

12. Due, P., et al. (2009). Socioeconomic Inequality in Exposure to Bullying During Adolescence: A Comparative, Cross-Sectional, Multilevel Study in 35 Countries. American Journal of Public Health, 99(5), 907-914.

13. Eisenberg, M.E., Neumark-Sztainer, D., \& Perry, C.L. (2003). Peer Harassment, School Connectedness, and Academic Achievement. Journal of School Health, 73(8), 311-316. doi: 10.1111/j.17461561.2003.tb06588.x 
14. Elgar, et al. (2015). Structural Determinants of Youth Bullying and Fighting in 79 Countries. Journal of Adolescent Health, 57(6), 643650. doi: 10.1016/j.jadohealth.2015.08.007

15. García, A.I.S, \& Margallo, E.M. (2014). Bullying: What's Going on? A Bibliographic Review of Last Twelve Months. Procedia - Social and Behavioral Sciences, 132, 269-276. doi:10.1016/j.sbspro.2014.04.309

16. Hair, J.F. Jr., Anderson, R.E., Tatham, R.L., \& Black, W.C. (1998). Multivariate data analysis ( ${ }^{\text {th }}$ Edition). Upper Saddle River, NJ: Prentice Hall.

17. Harel-Fisch, Y., et al. (2011). Negative school perceptions and involvement in school bullying: a universal relationship across 40 countries. Journal of Adolescence, 34(4), 639-652. doi: 10.1016/j.adolescence.2010.09.008

18. Hong, J.S., \& Espelage, D.L. (2015). A review of research on bullying and peer victimization in school: An ecological system analysis. Aggression and Violent Behavior, 17, 311-322. doi:10.1016/j.avb.2012.03.003

19. Lester, L., \& Mander, D. (2015). The Role of Social, Emotional and Mental Wellbeing on Bullying Victimisation and Perpetration of Secondary School Boarders. Journal of Psychologists and Counsellors in Schools, 25(2), 152-169. doi 10.1017/jgc.2014.28

20. Luk, J.W., Wang, J., \& Simons-Morton, B.G. (2010). Bullying Victimization and Substance Use. Prevention Science, 11, 355-359. doi: 10.1007/s11121-010-0179-0

21. Matos, M.G., Carvalho, M. \& Social Adventure Project Team (2014). Psychosocial Correlates of Violence over 8 Years. Asian Journal of Humanities and Social Studies, 2(2), 219-229.

22. Matos, M.G., Simões, C., Camacho, I., Reis, M. \& Equipa Aventura Social (2015). A Saúde dos Adolescentes Portugueses em Tempos de Recessão - Dados Nacionais do Estudo HBSC de 2014 ? [The Health of Portuguese Adolescents in Times of Recession - National Data from 2014 HBSC study]. Lisboa: IHMT/UNL, FMH/UL. ISBN: 978989-98346-1-3

23. Matos, M.G. (2014). Novos rumos na educação e promoção da saúde a partir de uma reflexão sobre a intervenção com crianças e adolescentes no trabalho do Aventura Social. [New directions in education and health promotion from a reflection on intervention with children and adolescents in the work of the Social Adventure]. Saúde e Tecnologia, 12, 5-7. ISSN: 1646 -9704

24. Matos, M.G., et al. (2015). “Dream Teens” - Adolescentes autónomos, responsáveis e participantes [“Dream Teens” - 
Autonomous, responsible and participative adolescents]. Journal of Child and Adolescent Psychology, 6(2), 47-58.

25. Matos, M.G. (2015). Adolescentes: navegação segura por águas desconhecidas. [Adolescents: safe navigation through unknown waters]. Lisboa: Coisas de Ler.

26. Mitchie, S., Spring, B., \&West, R. (2013) Moving from theory to practice and back in social and health psychology. Health Psychology, 32, 581-585.

27. Modecki, K.L., Minchin, J., Harbaugh, A.G., Guerra, N.G., \& Runions, K.C. (2014). Bullying Prevalence Across contexts: A Metaanalysis Measurng Cyber and Traditional Bullying. Journal of Adolescent Health, 55, 602-611. doi: 10.1016/j.jadohealth.2014.06.007

28. Nansel, T.R., Overpeck, M., Pilla, R.S., Ruan, W.S., Simons-Morton, B., \& Scheidt, P. (2001). Bullying behaviors among US youth: prevalence and association with psychosocial adjustment. The Journal of The American Medical Association, 285(16), 2094-2100.

29. Nansel, T.R., Craig, W., Overpeck, M.D., Saluja, G., Ruan, W.J., \& Health Behaviour in School-aged Children Bullying Analyses Working Group (2004). Cross-national consistency in the relationship between bullying behaviors and psychosocial adjustment. Archives of Pediatrics and Adolescent Medicine, 158(8), 730-736. doi: 10.1001/archpedi.158.8.730

30. Olweus, D. (1996). Bullying at School Knowledge Base and an Effective Intervention Program. Annals of the New York Academy of Science, 794(1), 265-276. 10.1111/j.1749-6632.1996.tb32527.x

31. Olweus, D. (1997). Bully/victim problems in school: Facts and intervention. European Journal of Psychology of Education, 12(4), 495-510.

32. Renshaw, T., Roberson, A., \& Hammons, K.N. (2016). The Functionality of Four Bullying Involvement Classification Schemas: Prevalence Rates and Associations with Mental Health and School Outcomes. School Mental Health, 8, 332-343. doi: 10.1007/s12310015-9171-y

33. Thomas, H.J., Chan, G.C.K., Scott, J.G., Connor, J.P., Kelly, A.B., \& William, J. (2016). Association of different forms of bullying victimisation with adolescents' psychological distress and reduced emotional wellbeing. Australian \& New Zealand Journal of Psychiatry, 50(4), 1-9. doi: 10.1177/0004867415600076

34. Valdebenito, S., Ttofi, M., \& Eisner, M. (2015). Prevalence rates of drug use among school bullies and victims: A systematic review and 
meta-analysis of cross-sectional studies. Aggression and Violent Behavior, 23 137-146. doi: 10.1016/j.avb.2015.05.004

35. Vieno, A., Gini, G., \& Santinello, M. (2011). Different forms of bullying and their association to smoking and drinking behavior in Italian adolescents. Journal of School Health, 81(7), 393-399. doi: 10.1111/j.1746-1561.2011.00607.x 